\title{
The Dynamics of the Efficiency of State Support to the Agro- \\ Industrial Complex on the Example of The Volga Federal District
}

\author{
Diaz R. Kadyrov \\ Kazan Federal University \\ Email: Diaz.Kadyrov@tatar.ru, Contact: +7 (919)681-80-50
}

Received: 15th December 2017, Accepted: 20th December 2017, Published: 31st December 2017

\begin{abstract}
The issues of improving the system of state regulation of agriculture have highly actualized subject to Russia's accession to the WTO. Based on the materials provided by the Ministry of Agriculture of the Russian Federation, the Ministry of Finance of the Russian Federation and the Center for Strategic Planning in the Agro-Industrial Complex, this paper deals with the behavior of the main indicators characterizing the effectiveness of measures of state support to the agro-industrial complex in the entities of the Federation of the Volga Federal District. The methods of comparative economic analysis were used, serving as the basis for groups of the VFD entities identified according to the criteria of profitability, impact of profitability and subsidies on the financial result. Such factor as profitability proved to be significant; in the Republic of Tatarstan it exceeds the facto of expenditures by 3.5 times. The analysis also revealed regions with abnormal indicators, such as Orenburg region - abnormally high indicators, and the Republic of Mari El - the most problematic area, requiring separate detailed consideration. As a result of the revealed imbalances, subject to the fact that the Russian Federation is gradually entering the WTO, it seems important to change the systems and methods of state support, regrouping if possible the state support funds of the village from the "yellow" to the 1 "green" 2 basket, and also use indicators per hectare, per liter and other more accurate indicators to determine the effectiveness of subsidies, which will reduce differentiation and disproportion and improve overall efficiency. As an example of the effectiveness of the proposed approach, the structure of these baskets for Saratov region as one of the developed and representative agricultural regions of the Russian Federation is presented.
\end{abstract}

Keywords: Agro-Industrial Complex, World Trade Organization (WTO), State Support, Efficiency, Budget, Volga Federal District.

\footnotetext{
${ }^{1}$ All state support costs for agriculture, not included in the "blue" and "green" baskets (aggregate support measures). ${ }^{2}$ Financial state costs that do not have a direct effect on the increase in production or on the terms of trade.
}

\section{Introduction}

In modern conditions, the problem of assessing the effectiveness of budget costs for the support for agricultural activities in the Russian Federation acquires special significance.

On the one hand, an unfavorable conjuncture in the hydrocarbon market caused difficulties arising with the formation of the revenue side of the budget and the stability of the ruble exchange rate, on the other hand, food supply security, living standards, social stability and import substitution became more acute as a result of devaluation.

The state support allows mitigating the consequences of non-equivalence in the exchange of agricultural goods with other sectors of the economy, create conditions for effective solution of the tasks of improving the quality of life, thus being an integral and important part of agrarian policy in virtually all developed countries.

Another one of the most important and urgent problems of Russian agriculture development remains unresolved in the context of the country's accession to the WTO, such as the transformation of the methods and ideology of support for the agro-industrial complex in the country. The need for the development and implementation of other complex and topical methods that will allow optimizing the costs for supporting agriculture in the conditions of competition and new budgetary constraints is exacerbated [5].

Thus, all initiatives on and studies of the rationalization of resource allocation procedures aimed at increasing the effectiveness of the use of budget funds appear to be extremely relevant and important.

\section{Literature Review;}

The effectiveness of the use of agricultural land, as well as the methodological tools for its assessment, are considered in the works by Russian scientists V.V. Butyrin, L.B. Vinichek, V.T. Vodiannikov, I.L. Vorotnikov, A.I. Dobrynin, V.A. Dobrynin, G.A. Dolgoshei, N.P. Kastornov, A.I. Kolobova, V.V. Kuznetsov, O.N. Kusakina, I.A. Minakov, Z.A. Mishina, N.T. Nazarenko, I.Ia. Petrenko, K.A. Petrov, I.A. Rodionova, G.V. Savitskaia and others. 
The works by A.A. Anfinogentova, E.V. Vasilieva, I.L. Vorotnikov, I.P. Glebov, N.I. Kuznetsov, I.F. Sukhanova, A.I. Trubilin, A.A. Cherniaev and others deal with the issues of state support for agricultural producers.

The problems of the development of the theory of economic and mathematical modeling, its practical application for forecasting and analysis of agrofood markets were studied by Aganbegian A.G., Arlazorov V.V., Bagrinovskii K.A., Dubovskii S.V., Kondratiev N.D., Kravchenko R.A., Kundysheva E.S., Romanenko I.A., Solou R., Svetlov N.M., Siptits S.O., Shtelmakher M. and others.

Many foreign and domestic scientists such as G.V. Bespakhotnyi, Gaisin R.S., Dubrovin E.N., Inozemtsev N.N., Keynes D., Krutov A.P., Leontiev V.V., Nikonov A.A., UzunV.Ia., Heine P., Hezlitt G., Horst H., Chaianov A.V. and others have studied the problems of forming an effective system of the mechanisms of state regulation.

The most qualitative research in the analysis of the economic impact of regulation belongs to such researchers as Robert Hahn [7], Claudio Radaelli [8], Andrea Renda [9], Scott Jacobs [10], and Colin Kirkpatrick [11]. The countries with the greatest experience in analyzing the quality of regulatory impact assessment are the EU and the USA.

The study also used the following: program documents, agreements, reports of working groups and data from the official WTO website [11-17].

Russia joined the WTO on August 22, 2012. This date can be considered the starting point of a new stage in the development of the country. By the way, it was the last of the "big twenty" to do this.

The existing WTO restrictions and rules require adaptation of international forms and methods of using state aid in the agro-industrial complex of Russia to ensure equal competitive conditions for producers of all participating countries. According to the requirements of the WTO, domestic measures on state support for agriculture in accordance with the requirements of the WTO are divided into four "baskets": "yellow", "green", "blue" and "deminimis rule" ${ }^{3}$. These tools are discussed in more detail in Table 1.

\footnotetext{
3"De minimis": a product-specific support in the amount of up to $5 \%$ (for developing countries - 10\%) of the value of agricultural products; a product-non-specific support, up to $5 \%$ (for developing countries $-10 \%$ ) of the value of agricultural products of the country [3].
}

Table 1 - State Support Measures for Agriculture and Rural Population (in Accordance with the Classification of the WTO Agriculture Agreement) $[2,7]$

\begin{tabular}{|c|c|c|c|}
\hline No. & $\begin{array}{l}\text { Forms of } \\
\text { support }\end{array}$ & Types of state support & $\begin{array}{l}\text { Applicability } \\
\text { in RF }\end{array}$ \\
\hline 1 & $\begin{array}{l}\text { Blue basket } \\
\text { measures }\end{array}$ & $\begin{array}{l}\text { State payments aimed at } \\
\text { reducing the number of } \\
\text { livestock, limiting the size of } \\
\text { farmland; monetary } \\
\text { compensations provided to } \\
\text { farmers in cases of voluntary } \\
\text { reduction of their production } \\
\text { volumes }\end{array}$ & $\begin{array}{l}\text { Not } \\
\text { applicable }\end{array}$ \\
\hline 2 & $\begin{array}{l}\text { Green basket } \\
\text { measures }\end{array}$ & $\begin{array}{l}\text { Financial state costs that do } \\
\text { not have a direct effect on the } \\
\text { increase in production or the } \\
\text { terms of trade (costs for crop } \\
\text { insurance, modernization of } \\
\text { rural social and engineering } \\
\text { infrastructure, information } \\
\text { support for agricultural } \\
\text { producers and development } \\
\text { of consulting services, } \\
\text { research and development, } \\
\text { and personnel policy) }\end{array}$ & Applicable \\
\hline 3 & $\begin{array}{l}\text { Yellow } \\
\text { basket } \\
\text { measures }\end{array}$ & $\begin{array}{l}\text { State support costs for } \\
\text { agriculture, not included in } \\
\text { the "blue" and "green" } \\
\text { baskets (aggregate support } \\
\text { measures). }\end{array}$ & $\begin{array}{l}\text { Advisable to } \\
\text { use to } \\
\text { stimulate } \\
\text { production }\end{array}$ \\
\hline 4 & $\begin{array}{l}\text { Measures of } \\
\text { "Special and } \\
\text { differentiated } \\
\text { mode" }\end{array}$ & $\begin{array}{l}\text { Investment subsidies and } \\
\text { subsidies for the acquisition } \\
\text { of material and technical } \\
\text { resources }\end{array}$ & $\begin{array}{l}\text { For } \\
\text { developed } \\
\text { countries } \\
\text { only }\end{array}$ \\
\hline
\end{tabular}


Before joining the WTO, Russia applied measures of domestic support for agriculture in the form of "green" and "yellow" baskets.

In 2011, before joining the WTO, the share of direct state support in Russia, which refers to the measures of the "yellow basket", was $80.5 \%$ or 101.9 billion rubles. (3.5 billion dollars), where more than $90 \%$ of support measures are productnon-specific. However, the main emphasis was placed on the tools of the "yellow basket". The share of "green basket" measures, which refers to the indirect form of state support, was only $19.5 \%$. While the measures of the "yellow basket" in developed countries are, as a rule, not the main regulator of financing of agriculture. For example, in the USA, the "yellow basket" accounts for only $4 \%$, and "green" - 90\% in the total amount of support.

Subject to strong dependence on import, deficit of national food on the domestic market for Russian manufacturers, the measures of the "blue basket" are not yet usual in application.

The key issue of supporting the APC in this way today is the transfer of state support from the "yellow" to "green" basket, using the experience of advanced countries. Despite the fact that their "yellow" basket is quite large, but at the same time a significant part of the support is concentrated in the "blue" basket, that is, in production limiting and restraining measures [4].

The adjustments in the structure and forms of state support of domestic agricultural production are associated with Russia's accession to the WTO. Since 2013, new forms of state support have been introduced, such as subsidies for 1 hectare of arable land in the amount of 15.2 billion rubles, or about 200 rubles per hectare. Subsidies from the federal budget are provided for 1 liter of marketed milk. For these purposes, 9.55 billion rubles are envisaged, i.e. 1 liter will account for about 1.5 rubles. These measures are not included in the "yellow basket" of support, so they can neither be limited according to WTO approaches, nor stimulate competition, and create additional opportunities for domestic producers.

\section{Methods}

Based on the available initial statistics of the Ministry of Agriculture of the Russian Federation, the Ministry of Finance of the Russian Federation and the Center for Strategic Planning in the AgroIndustrial Complex for 2013-2016, which present the results of the activities of the agro-industrial complex and the volumes of financial support, we shall try to evaluate the dynamics of the effectiveness of the volumetric parameters of state regulation [1].

For this, we use the traditional method of calculation - the ratio of the effect (profitability earnings before tax) and costs.

For the purposes of the study, we take the following figures and formulas:

Base year $-2013^{\circ}$

Fiscal year $-2016^{1}$

For calculation, formula 1 is used.

$P=R \times C$

Where $P$ - profit /loss before taxation;

$R$ - Profitability;

C-Costs (subsidies).

The initial data of calculations on an example of the VFD entities are presented in Fig. 1

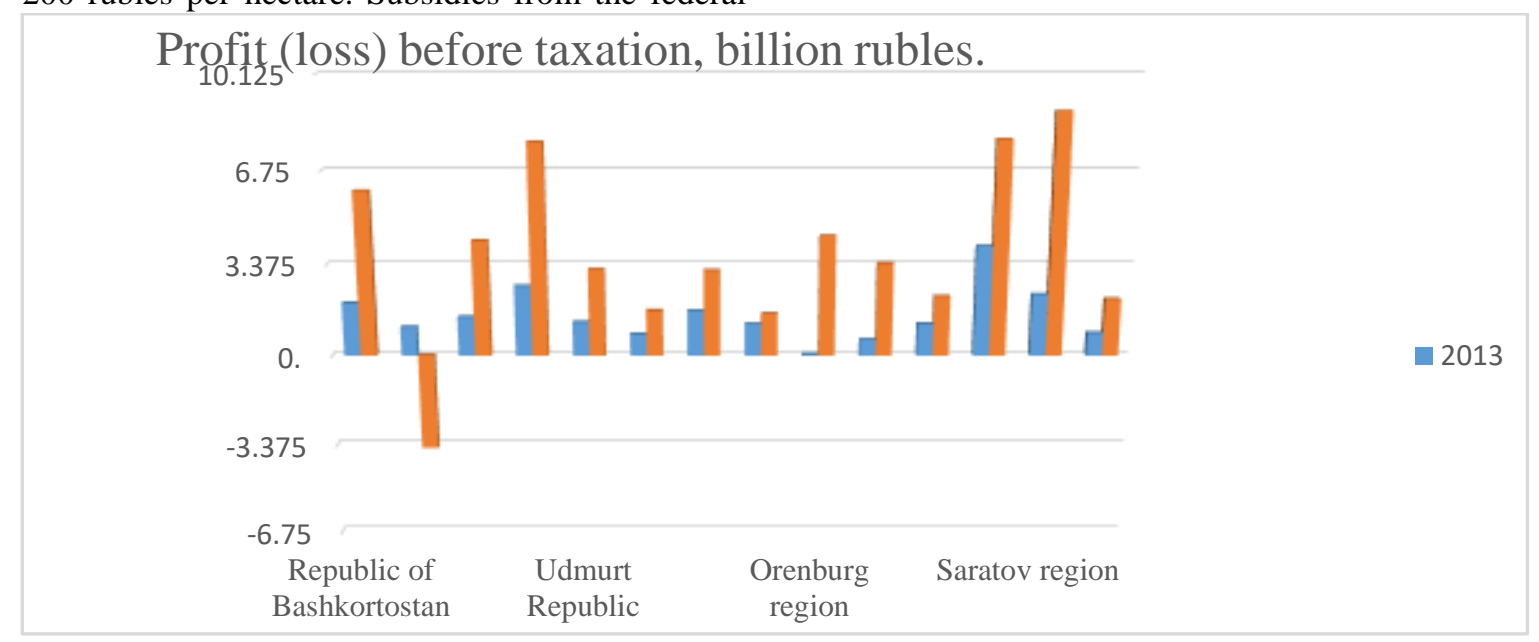

Fig. 1 - Profit (Loss) Before Taxation in the VFD for 2013, 2016. 
Such factors as the change in profitability and the change (subsidies) of costs affects the change in profit; we calculate it by the formula 2 .

$\Delta \mathrm{P}=\Delta \mathrm{P}_{\mathrm{R}}+\Delta \mathrm{P}_{\mathrm{c}}$

(2)

The effect of profitability is determined by the formula 3 .

$\Delta \mathrm{P}_{\mathrm{R}}=\left(\mathrm{R}_{\Pi}^{1}-\mathrm{R}_{\Pi}^{0}\right) \times \mathrm{C}^{1}$

The effect of subsidies (costs) on agricultural production is calculated by the formula 4 .

$\Delta \mathrm{P}_{3}=\mathrm{R}_{\mathrm{P}}{ }^{0} \times\left(\mathrm{C}^{1}-\mathrm{C}^{0}\right)$

(4)

Then the total change is calculated by the formula 5.

$\Delta \mathrm{P}=\Delta \mathrm{P}^{1}-\Delta \mathrm{P}^{0}$

$(5)$
We determine the growth rate under the influence of each factor and the overall growth rate in relative terms according to the formulas $6,7,8$.

$\mathrm{T}_{\text {gr PR }}=\left(\Delta \mathrm{P}_{\mathrm{R}} / \mathrm{P}^{0}\right) \times 100 \%$

(6)

$\mathrm{T}_{\text {gr PC }}=\left(\Delta \mathrm{P}_{3} / \mathrm{P}^{0}\right) \times 100 \%$

Then the overall growth rate is determined by the formula 8 or 9 .

$\mathrm{T}_{\text {gr } \mathrm{P}}=\mathrm{T}_{\text {gr PR }}+\mathrm{T}_{\text {gr } \mathrm{PC}}$

Or

$\mathrm{T}_{\text {gr } \mathrm{P}}=\left(\Delta \mathrm{P} / \mathrm{P}^{0}\right) \times 100 \%$

\section{Results}

As a result of using formulas 1-9 for calculations, the following data were obtained and systematized in Table 2.

Table 2 - Costs/Profitability Factor Model for 2013, 2016.

\begin{tabular}{|c|c|c|c|c|}
\hline The VFD entities & $\begin{array}{c}\text { Profitability- } \\
\text { influenced growth } \\
\text { rate } \boldsymbol{T}_{\boldsymbol{g r} \boldsymbol{P R}}(\%)\end{array}$ & $\begin{array}{l}\text { Growth rate under } \\
\text { the influence of } \\
\text { subsidies (costs) for } \\
\text { agricultural } \\
\text { production } \boldsymbol{T}_{\boldsymbol{g r}} \\
\boldsymbol{P C}(\%)\end{array}$ & $\begin{array}{l}\text { Overall growth rate } \\
\qquad \boldsymbol{T}_{\operatorname{gr} \boldsymbol{P}}(\%)\end{array}$ & Group \\
\hline $\begin{array}{l}\text { Republic of Bashkortostan } \\
\text { (Agr.) }\end{array}$ & 161.44 & 48.66 & 210.10 & 1 \\
\hline Republic of Mari El (Agr.) & -477.86 & 45.17 & -432.68 & 3 \\
\hline Republic of Mordovia (Agr.) & 126.41 & 70.32 & 196.73 & 2 \\
\hline Republic of Tatarstan (Agr.) & 159.01 & 42.62 & 201.63 & 1 \\
\hline Udmurt Republic (Agr.) & 116.85 & 39.96 & 156.80 & 2 \\
\hline Republic of Chuvashiya (Agr.) & 61.78 & 49.41 & 111.19 & 2 \\
\hline Kirov region (Agr.) & 47.26 & 41.95 & 89.21 & 3 \\
\hline $\begin{array}{l}\text { Nizhny Novgorod region } \\
\text { (Agr.) }\end{array}$ & -1.60 & 34.41 & 32.81 & 3 \\
\hline Orenburg region (Agr.) & $12,249.84$ & 35.77 & $12,285.61$ & 1 \\
\hline Penza region (Agr.) & 402.79 & 87.20 & 489.98 & 1 \\
\hline Perm Krai (Agr.) & 52.79 & 33.60 & 86.39 & 3 \\
\hline
\end{tabular}




\begin{tabular}{|l|c|c|c|c|}
\hline Samara region(Agr.) & 52.37 & 42.70 & 95.08 & 3 \\
\hline Saratov region (Agr.) & 229.02 & 62.52 & 291.55 & 1 \\
\hline Ulyanovsk region (Agr.) & 92.91 & 57.60 & 150.51 & 2 \\
\hline
\end{tabular}

The data in Table 2 allow us to divide the VFD entities into groups according to the degree of influence of the factors on profit, as a financial result, which are differently colored in the table.

\section{Summary}

According to the calculations in Table 2, we present a diagram of the general effect of the factors on profit (Fig. 2).

Group 1: this group of entities is characterized by the significant influence of the factor - profitability and high profit before taxation in the range of 4-8.5 billion rubles; it includes: Saratov region, the Republic of Tatarstan, Orenburg region, the Republic of Bashkortostan, and Penza region.

Group 2: shows the average level of influence of factors and profit - [1-2.5 billion rubles]; it includes: the Republic of Mordovia, the Udmurt Republic, the Chuvash Republic, and Ulyanovsk Region.

Group 3: shows low level of influence of factors and profit; it includes: Samara Region, Perm Territory, Kirov Region, and Nizhny Novgorod Region.

We should particularly note the Republic of Mari $\mathrm{El}$, which has a problematic dynamics and requires detailed research.

\section{Discussion}

Further research activity is aimed at using best practices and focusing on those regions that have achieved better results (groups 1 and 2) and recommending their approaches for reformatting state support measures for regions with low indicators, as they are located in one natural and climatic zone.

The main task is to focus on improving the efficiency of the transition to the "green" basket during the first stage, and to the blue basket in the long run, as well as to show the actual change in the efficiency of this transition.

\section{Acknowledgements}

The work is performed according to the Russian Government Program of Competitive Growth of Kazan Federal University. We express our gratitude to the Ministry of Agriculture of the Russian Federation, the Federal Treasury, the Ministry of Finance of the Russian Federation, the Center for
Strategic Planning in the Sphere of the AgroIndustrial Complex and the head of the Federal Treasury Department's Center for Ensuring the Activity of the Treasury of Russia in Kazan, and to Amina Savadakhanovna Khusainova.

\section{References}

1. Sablina E.A. Finance statistics: a study guide // E.A. Sablina. - M.: Pub. house "Ekzamen", 2006. p. 253.

2. Grishin A.F. Statistical models in economics // A.F. Grishin - Rostov-on-Don: "Fenix", 2005. - p. 344.

3. Dougherty K. Introduction to Econometrics: trans. Eng. - M.: INFRA-M, 1999. - XIV, p. 402.

4. Implementation of agricultural potential of the region: Monograph. Authors: P.S. Shepitko, I.S. Korabelnikov, A.V. Nemchenko, N.N. Balashova, E.N. Kashinskaia, T.A. Dugina, A.V. Boldyrev. 2016 - p. 190.

5. Trends in the development of the world market of agricultural products: effects. Authors: A. Ivolga, V. Erokhin, I. Ivolga. - 2013 - p. 150.

6. The Agreement on Agriculture URL:http://www.wto.ru/content/documents/docs/se lhozru.doc.

7. The Agreement on Subsidies and Countervailing Measures URL: http://www.wto.ru/content/documents/docs/subsko mp.doc.

8. Lang M. et al (eds.) WTO and Direct Taxation //Linde Verlag, Vienna, 2005

9. A report of the working group on Russia's accession to the WTO. The document is authentic in English only. 11/16/2011.

10. Agricultural Policy Monitoring and Evaluation 2013. OECD Countries and Emerging. Economies. OECD, 2013, Paris.

11. Martini, R. (2011) «Long term Trends in agricultural Policy Impacts». OECD, PapOrs№45

12. The agri-food sector in Russia: Current Situation and market outlook until 2025. European Union, 2013. 